\title{
Market Survey on Adoption and Utilization of Post- Harvest \& Agro Processing Technologies in Uasingishu County, Kenya
}

\author{
${ }^{1}$ Ouma, R.O, ${ }^{2}$ Mugalavai, V.K \& ${ }^{3}$ Onkware, A. O \\ ${ }^{1}$ Business Studies Department, Rongo University, Kenya \\ ${ }^{2}$ Department of Family \& Consumer Sciences, University of Eldoret, Kenya \\ ${ }^{3}$ Department of Biological Sciences, Rongo University, Kenya \\ DOI: 10.29322/IJSRP.10.05.2020.p10147 \\ http://dx.doi.org/10.29322/IJSRP.10.05.2020.p10147
}

\begin{abstract}
Post-harvest and agro-processing losses in the rural farming communities in Kenya is a major challenge because of the level of knowledge, skills and technologies used by majority of these farmers in many parts of the country. The aim of the survey was to analyze the utilization of post-harvest and agro-processing technologies through market analysis of the existing technologies. The market survey was carried out in Elgeyo Marakwet and Uasin Gishu counties whereby the focus was Iten town and Eldoret town which form the major urban centers of the counties where farmers buy post-harvest and agro processing technologies. For the postharvest technologies the target establishments included; Agrovets, Farm machinery shops, Jua kali and Supermarkets. Sampling was done using stratified sampling where streets were used to divide the town followed by simple random sampling of the establishments. In some instances cluster sampling was used in scenarios where same establishment were concentrated in one area as in the case of the jua kali. Data collection for this study was purely through questionnaires and observations. Descriptive statistic methods of data analysis were employed. The study found out that most post-harvest technologies were not utilized by farmers therefore there is need for the relevant authorities to do awareness on available methods of post-harvest handling and agro processing of food and feed. At the point of sale too it was noted that those who were in such businesses would also be educated on the existence of other post-harvest technologies so that when farmers visit them then they could educate them. Most of the cheap technologies were locally made in the jua kali as compared to supermarkets which were more expensive. There is need for the jua kali artisans to be trained on how to modernize so as to be able to sell some of their products to the supermarkets and for them to be able to commercialize the production of the post-harvest technologies. There is a need for an exhibition with the stakeholders to create awareness on all post-harvest technologies available in the market place.
\end{abstract}

\section{INTRODUCTION}

$\mathrm{H}$ unger, malnutrition, and poverty are persistent issues in many developing countries despite recent advances in agriculture productivity. By 2050 , the world's population is projected to reach 9 billion, 34 percent higher than today. Nearly all of this increase will occur in developing countries (FAO 2015, IFPRI, 2015). The number of the hungry is 350 million in subs Saharan Africa (FAO, 2015). Yet, one third of the world's available food is lost, spoilt or wasted before it even reaches a plate: and this loss is said to be enough to feed everyone in the world for two months. Food loss is the diminishing quantity of edible food through production, harvest, post-harvest and processing stages of the supply chain, which may be occasioned by spillage, pest and microbial infestations, for example. Such food loss and wastage can be minimized through greater investments, and wider adoption of improved post-harvest and agro-processing (PHAP) technologies. Adoption of these technologies and improving management practices can be of great help in terms of national and global food security (IFPRI, 2015), and in support of the Right to Food for all (GoK, 2013).

Studies carried out in various parts of Kenya established that the major cereal grains, such as sorghum and maize undergo significant post- harvest losses at threshing, storage and processing (Nyambo, 2013). It has also been argued that food availability can be significantly increased without having to increase production by curbing the postharvest losses (Hodges et al, 2011). In the smallholder farm units the postharvest losses affect women the most because they are responsible for drying, storage and processing of grain for household use. Improvement in shelling/threshing, drying, storage, exclusion of larger pests such as mice; and processing techniques, such as fermentation are some of the practices that can be used to cut down on postharvest losses and contamination. Most of the farmers in these countries have not adopted improved technologies in postharvest handling. Consequently they need exposure and training on the use of these technologies as well as access to inputs, materials and markets (Suvedi et al., 2016). Thus the aim of the survey was to analyze the utilization of post-harvest and agro-processing technologies through market analysis of the existing technologies.

\section{DATA PRESENTATION, INTERPRETATION AND DISCUSSION}

\section{Normalcy of Data}

The most important thing was to know if the data used was normal. The normality was assessed using measures of skewness and kurtosis (Tabachnick and Fidell, 2007). From the results of skewness (-1.25) and kurtsosis (1.647) the values lie within the 
range $+/-2$ The distribution was considered normal if skewness and kurtosis values fell within the interval -2.0 to 2.0. As shown in Table 1.1, the skewness and kurtosis values for all variables were within the acceptable interval. Normality assumptions were therefore met.

\begin{tabular}{|c|c|c|c|c|}
\hline & $\begin{array}{l}\text { is of the existen } \\
\text { gy }\end{array}$ & e of the & Statistic & $\begin{array}{l}\text { Std. } \\
\text { Error }\end{array}$ \\
\hline \multirow{13}{*}{$\begin{array}{l}\text { Farmers } \\
\text { knowledge } \\
\text { on how to } \\
\text { use the } \\
\text { technology }\end{array}$} & \multicolumn{2}{|l|}{ Mean } & 4.22 & 0.132 \\
\hline & \multirow[t]{2}{*}{$\begin{array}{l}95 \% \text { Confidence } \\
\text { Interval for Mean }\end{array}$} & $\begin{array}{l}\text { Lower } \\
\text { Bound }\end{array}$ & 3.96 & \\
\hline & & $\begin{array}{l}\text { Upper } \\
\text { Bound }\end{array}$ & 4.48 & \\
\hline & \multicolumn{2}{|l|}{$5 \%$ Trimmed Mean } & 4.31 & \\
\hline & \multicolumn{2}{|l|}{ Median } & 4 & \\
\hline & \multicolumn{2}{|l|}{ Variance } & 0.869 & \\
\hline & \multicolumn{2}{|l|}{ Std. Deviation } & 0.932 & \\
\hline & \multicolumn{2}{|l|}{ Minimum } & 1 & \\
\hline & \multicolumn{2}{|l|}{ Maximum } & 5 & \\
\hline & \multicolumn{2}{|l|}{ Range } & 4 & \\
\hline & \multicolumn{2}{|l|}{ Interquartile Range } & 1 & \\
\hline & \multicolumn{2}{|l|}{ Skewness } & -1.25 & 0.337 \\
\hline & \multicolumn{2}{|l|}{ Kurtosis } & 1.647 & 0.662 \\
\hline
\end{tabular}

\section{Background Characteristics of the Study Population}

The study established the demographic characteristics of the respondents, including their gender, age, highest academic qualification, business ownership, how the business was started up and the amount of the initial capital.

\section{Demographic Characteristics of Respondents.}

Respondents were asked to indicate their demographic data in the questionnaire, Results in Figure 1.1 indicated a majority
66.7 percent were male while 33.3 percent were female majorly aged between $21-40(80.6 \%)$ years with $16.7 \%$ aged $41-60$ years and only $2.8 \%$ aged less than 20 years, furthermore from the study it was established that $94.4 \%$ were married with only slightly more than $5 \%$ who were single. On examining their academic levels majority were of secondary school level at $58.3 \%, 38.9 \%$ had primary and $2.8 \%$ had tertiary level of education. All the respondents interviewed held different posts in the establishment ranging from managerial to the support staff who had different skills in line with their jobs.

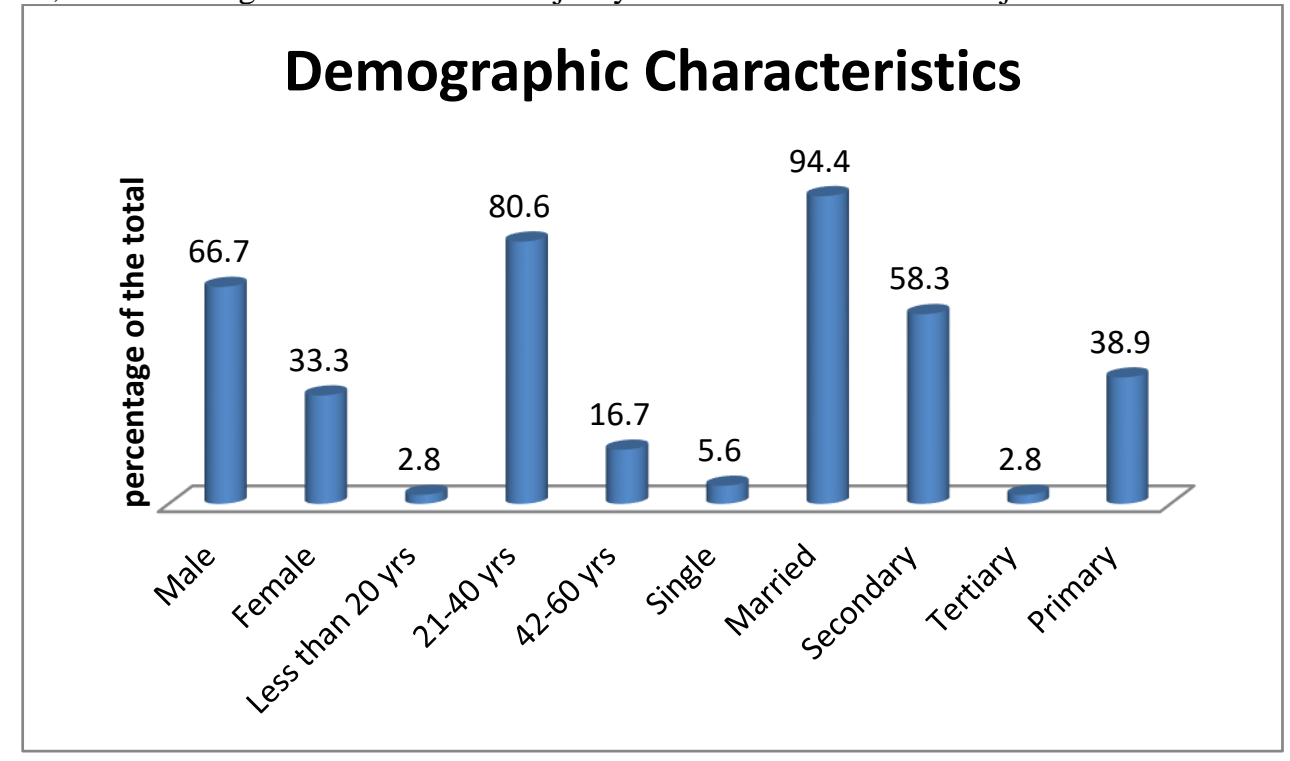

Figure 1.1: Demographic characteristics of respondents 


\section{Ownership of the Business}

As shown in Figure 1.2, results of this study indicated that for those interviewed, $44.4 \%$ owned the businesses while slightly more than half $(55.6 \%)$ were employees in various capacities of the establishments visited

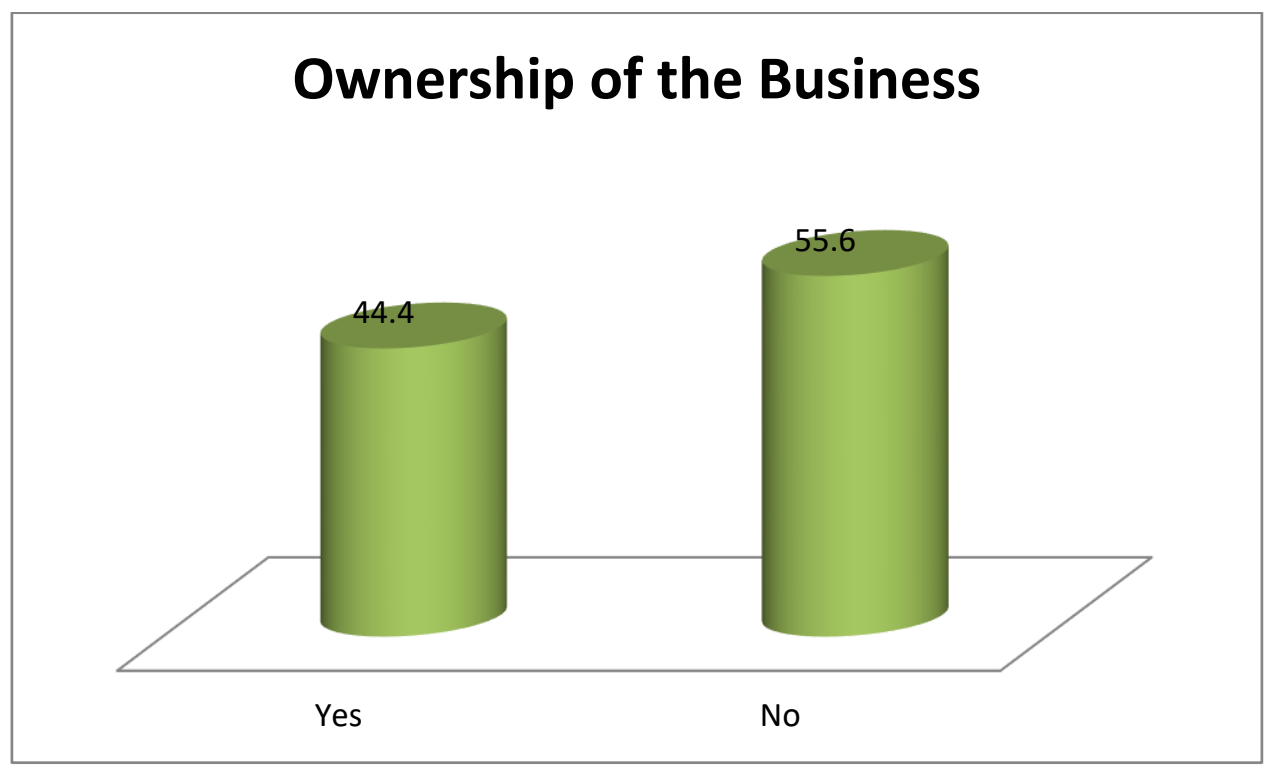

Figure 1.2: Ownership of Business

\section{Number of Years involved in the Business}

The respondents were asked to disclose the number of years they have been involved in the business, the Table below shows that majority of the respondents $(63.9 \%)$ have been involved for less than ten years while $(30.6 \%)$ have been in the business for between 11 and 19 years, Only a small percentage $(5.6 \%)$ have been in the business for 20 years or more this is shown in Table 1.2 below

\begin{tabular}{|llllll|} 
Table 1.2: Number of years involved in the business \\
& & Frequency & Percent & $\begin{array}{l}\text { Valid } \\
\text { Percent }\end{array}$ & $\begin{array}{l}\text { Cumulative } \\
\text { Percent }\end{array}$ \\
\hline Valid & less than 10 & 23 & 63.9 & 63.9 & 63.9 \\
\cline { 2 - 6 } & $11-19$ yrs. & 11 & 30.6 & 30.6 & 94.4 \\
\cline { 2 - 6 } & $21-30$ yrs. & 2 & 5.6 & 5.6 & 100.0 \\
\hline Total & 36 & 100.0 & 100.0 & \\
\hline
\end{tabular}

\section{Source of capital and the initial capital}

\section{Source of capital}

When respondents were asked about how the business was started up $30.6 \%$ did not know how the business was started up because they were either just employees or they were not there when the business was started up, for those respondents who knew how the business was started majority of the businesses had own initial capital from savings at $38.9 \%$ while $13.9 \%$ were started up by family contributions and $13.9 \%$ were started by using loans from the financial institutions while $2.8 \%$ were started by both loans and own savings as shown in fig 1.3 below 


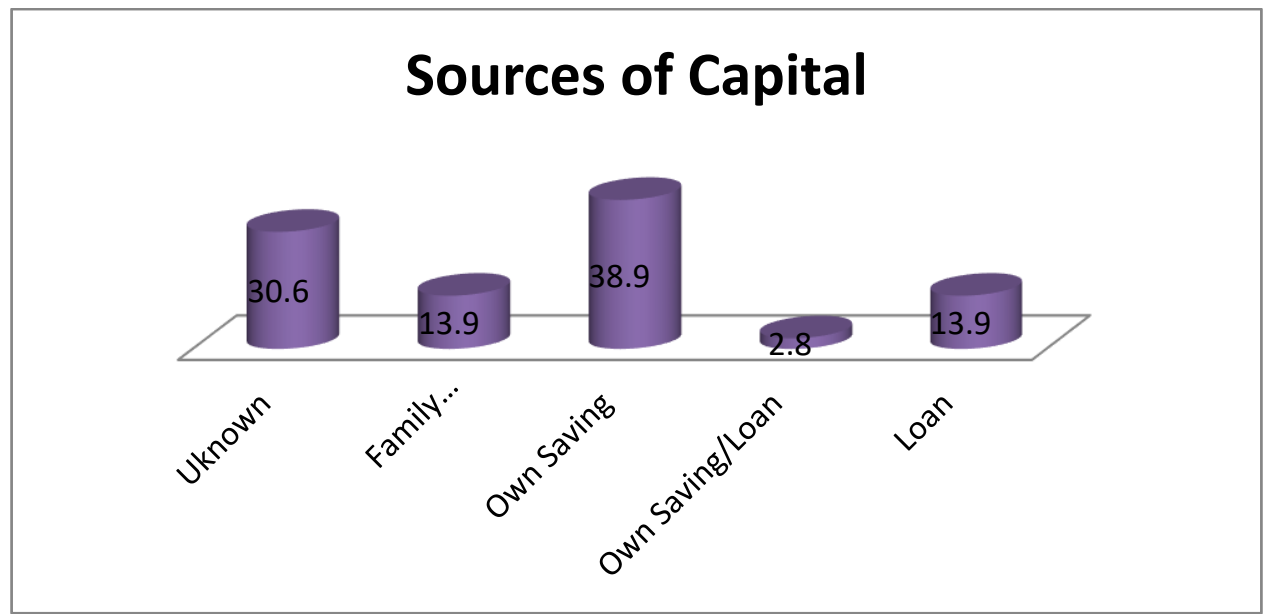

Figure 1.3: Source of Capital

\section{Initial capital}

When respondents were asked about the business initial capital 33.3\% did not know the amount of the initial capital because they were just but employees, for those respondents who knew the initial capital majority of the businesses had an initial capital of less than KES 50000/- at 44.4\% while $8.3 \%$ had an initial capital of more than between KES 50000/- and 100000/-, while only $13.9 \%$ had an initial capital of more than KES 100000/- as indicated in Table 1.3

\begin{tabular}{|l|l|l|l|l|l|}
\hline \multicolumn{2}{|l|}{ Table 1.3: Initial Capital } & Frequency & Percent & $\begin{array}{l}\text { Valid } \\
\text { Percent }\end{array}$ & $\begin{array}{l}\text { Cumulative } \\
\text { Percent }\end{array}$ \\
\hline \multirow{3}{*}{ Valid } & Less than KES 50000/- & 16 & 44.4 & 66.7 & 66.7 \\
\cline { 2 - 6 } & $\begin{array}{l}\text { Between KES 50000/- \& } \\
100000\end{array}$ & 3 & 8.3 & 12.5 & 79.2 \\
\cline { 2 - 6 } & & & & & \\
\cline { 2 - 6 } & More than 100000/- & 5 & 13.9 & 20.8 & 100.0 \\
\cline { 2 - 7 } & Total & 24 & 66.7 & 100.0 & \\
\hline Missing & System & 12 & 33.3 & & \\
\hline Total & 36 & 100.0 & & \\
\hline
\end{tabular}

Availability of Post-harvest Handling and Agro processing Technologies

We sought to find out the availability of post-harvest handling technologies in Agro vets, Machinery shops, Open air markets or jua kali and supermarkets for all the supermarkets that were visited they did not have any of the listed post-harvest handling and agro processing technologies.

\section{Agrovets}

From the Agrovets it was found out that they had two technologies which were available this included; dehulling and storage technologies.

\section{Dehulling}

For Dehulling we found out that they available items were Actellic ,Skana and Nova supplied by Twiga industries, Nova industries and Osho Chemicals, for the sizes it ran from 50g to $25 \mathrm{~kg}$ for Actellic and Nova and $100 \mathrm{~g}$ to $2 \mathrm{~kg}$ for Skana ranging from 70/- to 17500/- and 100/- to 450/- for Skana. Quantities sold per annum ranged from $746 \mathrm{kgs}$ to a maximum of 3 tonnes for all the three products and their customers were local farmers all this information is shown in the Table (1.4) below. 


\section{Case summaries on Dehulling technology}

Storage

For the storage technology it was found out that the available items were pic Bags, Agroz and Elite Bags which were mostly supplied by elite companies and sold at between 200 \&
250/- per either 90kgs, 100kgs or $105 \mathrm{kgs}$ bag. Quantities sold per annum ranged from 100 to 5000 pieces to mostly local farmers as shown on the Table (1.5) below.

Table 1.5 Case summaries on storage technologies

$\begin{array}{lllllll}\text { Item use of } & \text { model/brand available size } & \text { supplier } & \text { price } & \begin{array}{l}\text { quantities } \\ \text { sold P.A }\end{array} & \begin{array}{l}\text { Customers } \\ \text { buying }\end{array}\end{array}$

\begin{tabular}{|c|c|c|c|c|c|c|c|}
\hline $\begin{array}{l}\text { Hermatic } \\
\text { Bag }\end{array}$ & Storage & Elite Bags & $100 \mathrm{kgs}$ & $\begin{array}{l}\text { Elite } \\
\text { Company }\end{array}$ & 250 & 152 & $\begin{array}{l}\text { Local } \\
\text { farmers }\end{array}$ \\
\hline Elite Bags & Storage & Elite & $105 \mathrm{kgs}$ & $\begin{array}{l}\text { Elite } \\
\text { Company }\end{array}$ & 200 & 5000 & $\begin{array}{l}\text { Local } \\
\text { farmers }\end{array}$ \\
\hline Elite Bags & Storage & Pics & $90 \mathrm{kgs}$ & $\begin{array}{l}\text { Elite } \\
\text { Company }\end{array}$ & 250 & 100 & $\begin{array}{l}\text { Local } \\
\text { farmers }\end{array}$ \\
\hline Elite Bags & Storage & Elite & $105 \mathrm{kgs}$ & $\begin{array}{l}\text { Elite } \\
\text { Inovation }\end{array}$ & 250 & 500 & $\begin{array}{l}\text { Local } \\
\text { farmers }\end{array}$ \\
\hline Pics & Storage & Pics & $100 \mathrm{kgs}$ & Pics & 250 & 500 & $\begin{array}{l}\text { Local } \\
\text { farmers }\end{array}$ \\
\hline Agroz/Elite & Storage & Treated Bags & $100 \mathrm{kgs}$ & Agroz/Elite & $\begin{array}{l}200- \\
250 / 250\end{array}$ & $50000 \& 10000$ & $\begin{array}{l}\text { Local } \\
\text { farmers }\end{array}$ \\
\hline Pics & Storage & $\begin{array}{l}\text { Perdue } \\
\text { University }\end{array}$ & $100 \mathrm{ks}$ & $\begin{array}{l}\text { Bell } \\
\text { Industries }\end{array}$ & 250 & 5000 & $\begin{array}{l}\text { Local } \\
\text { farmers }\end{array}$ \\
\hline Elite/pics & Storage & & $105 / 100 \mathrm{kgs}$ & Elite/bell & 200 & 1000 & $\begin{array}{l}\text { Local } \\
\text { farmers }\end{array}$ \\
\hline Pics & Storage & Bell Industries & $100 \mathrm{kgs}$ & $\begin{array}{l}\text { Bell } \\
\text { Industries }\end{array}$ & 250 & 2tonnes & $\begin{array}{l}\text { Local } \\
\text { farmers }\end{array}$ \\
\hline Elite/pics & Storage & Nylon & $100 \mathrm{kgs}$ & $\begin{array}{l}\text { Bell } \\
\text { Industries }\end{array}$ & 250 & 10000 & $\begin{array}{l}\text { Local } \\
\text { farmers }\end{array}$ \\
\hline
\end{tabular}

Machinery shop

\begin{tabular}{|c|c|c|c|c|c|c|c|}
\hline Item & $\begin{array}{l}\text { use of } \\
\text { technology }\end{array}$ & model/brand & $\begin{array}{l}\text { available } \\
\text { size }\end{array}$ & supplier & price & $\begin{array}{l}\text { quantities } \\
\text { sold P.A }\end{array}$ & $\begin{array}{l}\text { Customers } \\
\text { buying }\end{array}$ \\
\hline Actellic & Dehulling & Twiga & $1-25 \mathrm{~kg}$ & Twiga & $80-11360$ & 2tonne & Local farmers \\
\hline Actellic/skana & Dehulling & Pesticide & $\begin{array}{l}50 \mathrm{~g}-25 \mathrm{~kg} \\
\& 100 \mathrm{~g}- \\
2 \mathrm{~kg}\end{array}$ & Twiga/osho & $\begin{array}{l}100-12000 \& \\
100-450\end{array}$ & & Local farmers \\
\hline Actellic & Dehulling & Sygenta & $50 \mathrm{~g}-25 \mathrm{~kg}$ & Twiga & $70-100$ & $746 \mathrm{kgs}$ & Local farmers \\
\hline Actellic & Dehulling & Twiga & $50 \mathrm{~g}-25 \mathrm{~kg}$ & Twiga & $100-17500$ & 1tonne & Local farmers \\
\hline Actellic/Nova & Dehulling & Powder & $50 \mathrm{~g}-25 \mathrm{~kg}$ & Twiga/Nova & $80-13000$ & 3tonnes & Local farmers \\
\hline
\end{tabular}


For machinery shops technologies for drying, decortication and Milling were found. For seed drying, storage and decortication it was found in only one shop. The seed drier had an available size of 3 tonne sold to Locals at a price of 280000/-, A decortication machine ranging 6.5-7.5 horse power supplied by wonder machinery at a price of 40000 was sold to Locals, a storage bin was also available at Eldoret farm machinery at a price of 220000 its size was 2tonnne and four pieces were sold to local famers. For the Milling technologies Milling machines having different sizes and sold between 24000/- and 140000/- were sold to local farmers also various quantities were sold as shown in the Table (1.6) below

Table1.6: Available post-harvest technologies

\begin{tabular}{|c|c|c|c|c|c|c|c|}
\hline Item & $\begin{array}{l}\text { Use of } \\
\text { technology }\end{array}$ & Model/brand & $\begin{array}{l}\text { Available } \\
\text { size }\end{array}$ & Supplier & Price & $\begin{array}{l}\text { Quantitie } \\
\text { s sold P.A }\end{array}$ & $\begin{array}{l}\text { Customer } \\
\text { s buying }\end{array}$ \\
\hline $\begin{array}{l}\text { Seed } \\
\text { dryer }\end{array}$ & Drying & EEfm & 3tonne & Efm & 280000 & 3 & Locals \\
\hline Sheller & $\begin{array}{l}\text { Decorticatio } \\
\mathrm{n}\end{array}$ & japan-girasol & $6.5-7.5 \mathrm{HP}$ & $\begin{array}{l}\text { Wonder } \\
\text { Machinery }\end{array}$ & 40000 & 10 & Locals \\
\hline Bin & Storage & Efm & 2tonne & Efm & 220000 & 4 & Locals \\
\hline $\begin{array}{l}\text { Poshomil } \\
\text { l }\end{array}$ & Milling & Shakti & $22 \& 25$ & BMG & 120000 & 10 & $\begin{array}{l}\text { Business } \\
\text { men }\end{array}$ \\
\hline $\begin{array}{l}\text { Poshomil } \\
\text { l }\end{array}$ & Milling & Natasha & $10 \& 16 \mathrm{HP}$ & $\begin{array}{l}\text { World } \\
\text { machinery/T } \\
\text { asha }\end{array}$ & $\begin{array}{l}60000 \& \\
95000\end{array}$ & 12 & Locals \\
\hline Feed mill & Milling & Efm & DPM04 & Efm & 150000 & 10 & Locals \\
\hline $\begin{array}{l}\text { Fodder } \\
\text { mill }\end{array}$ & Milling & Komacs & GM 22 mill & $\begin{array}{l}\text { Spring } \\
\text { valley }\end{array}$ & 95000 & 15 & Locals \\
\hline $\begin{array}{l}\text { Poshomil } \\
\text { l }\end{array}$ & Milling & 721325-4(uk) & $7.5 \mathrm{hp}$ & CIGMA-UK & 75000 & 5 & Locals \\
\hline $\begin{array}{l}\text { Poshomil } \\
\text { l }\end{array}$ & Milling & Natasha/local & $\begin{array}{l}\text { Electricity/die } \\
\text { sel }\end{array}$ & Tasha & $\begin{array}{l}75000 \& 14 \\
000\end{array}$ & 30 & Locals \\
\hline $\begin{array}{l}\text { Poshomil } \\
\text { l }\end{array}$ & Milling & GM 20 & $7 \mathrm{hp}$ & local & 24000 & 7 & Locals \\
\hline $\begin{array}{l}\text { Poshomil } \\
\text { l }\end{array}$ & Milling & $\begin{array}{l}\text { Natasha/power } \\
\text { force }\end{array}$ & $\begin{array}{l}5 \& 10 \mathrm{hp} / 3 \& 5 \\
\text { phase }\end{array}$ & Tasha & $\begin{array}{l}80000- \\
140000\end{array}$ & $\begin{array}{l}200 \& 150 / \\
150 \& 250\end{array}$ & Locals \\
\hline
\end{tabular}

\section{Jua kali or open Air markets}

From the Table above technologies for postharvest and agro processing included technologies for cleaning, drying, storage and mixing as shown on the Table, for cleaning metal sieves of various size were available and retailing at a price of 300 to 3000 , for drying there was a locally made "tandarua" from bags used for drying its prices was between 100-1800 depending on the size and mostly sold to local farmers, for mixing a mixer was available which was used for mixing and sold at a price of 15000 to local farmers finally for storage there were various items for storage ranging from plastic to metallic retailing at a price ranging from 30 to 12000/- from various suppliers and sold to the local farmers, for cooking technologies there were ovens, Improved jikos and baking tins available for sale to local farmers, for the ovens it had various sizes ranging from small to large or $2.5 \mathrm{ft}$ to $5 \mathrm{ft}$ and sold between KES6000/- to 48000/- , for the improved jikos sizes ranged from 9" to 24" in diameter sold between KES 120 - to $340 \mathrm{0/-}$, baking tins which were available in size ranging from $200 \mathrm{~g}$ to $2 \mathrm{~kg}$ were sold between KES70 to 350 as show on the Table (1.7) below. 
Table1.7: Available Post-harvest Technologies in Jua Kali

\begin{tabular}{|c|c|c|c|c|c|c|c|}
\hline Item & $\begin{array}{l}\text { Use of } \\
\text { technology }\end{array}$ & Model/Brand & $\begin{array}{l}\text { Available } \\
\text { size }\end{array}$ & Supplier & Price & $\begin{array}{l}\text { Quantities } \\
\text { sold P.A }\end{array}$ & $\begin{array}{l}\text { Customers } \\
\text { buying }\end{array}$ \\
\hline Metal sieve & Cleaning & Jua kali & $1 \mathrm{~m}$ and $36 \mathrm{ft}$ & Jua kali & $2500 / 3000$ & 15 & $\begin{array}{l}\text { Local } \\
\text { famers }\end{array}$ \\
\hline Metal sieve & Cleaning & Jua kali & varied & Jua kali & $300-1000$ & 213 & $\begin{array}{l}\text { Local } \\
\text { farmers }\end{array}$ \\
\hline Tandarua & Drying & Jua kali & $\begin{array}{l}\text { 20/30/50/100 } \\
\text { bags }\end{array}$ & Jua kali & $100-1800$ & 100 & $\begin{array}{l}\text { Local } \\
\text { farmers }\end{array}$ \\
\hline Gala & Storage & Jua kali & $900 \mathrm{kgs}$ & Jua kali & 15000 & 4 & $\begin{array}{l}\text { Local } \\
\text { farmers }\end{array}$ \\
\hline \multirow[t]{2}{*}{ Metal drum } & Storage & Jua kali & $3 \mathrm{ft} 5 \mathrm{~m}$ & Jua kali & 7500 & 15 & $\begin{array}{l}\text { Local } \\
\text { farmers }\end{array}$ \\
\hline & Storage & Jua kali & $6 \& 12$ & Jua kali & $7000 \& 12000$ & $30 \& 2$ & $\begin{array}{l}\text { Local } \\
\text { farmers }\end{array}$ \\
\hline Bags & Storage & Jua kali & $90 \mathrm{kgs}$ & Unga & 30 & 5000 & $\begin{array}{l}\text { Local } \\
\text { farmers }\end{array}$ \\
\hline Drum & Storage & Jua kali & $135 / 180 \mathrm{~kg}$ & Raiply & $1300 / 2200$ & 55 & $\begin{array}{l}\text { Local } \\
\text { farmers }\end{array}$ \\
\hline Super Drum & Storage & Jua kali & $200 \$ 2501$ & Vitafoam & $1000 \& 2500$ & 1000 & $\begin{array}{l}\text { Local } \\
\text { farmers }\end{array}$ \\
\hline Plastic Drum & Storage & Jua kali & $250 \mathrm{kgs}$ & $\begin{array}{l}\text { Business } \\
\text { man }\end{array}$ & 3500 & & $\begin{array}{l}\text { Local } \\
\text { farmers }\end{array}$ \\
\hline $\begin{array}{l}\text { Plastic } \\
\text { container }\end{array}$ & Storage & Jua kali & 2501 & Jua kali & 3000 & 500 & $\begin{array}{l}\text { Local } \\
\text { farmers }\end{array}$ \\
\hline Mixer & Mixing & Jua kali & $\begin{array}{l}\text { Small to } \\
\text { Large }\end{array}$ & Jua kali & 15000 & 4 & $\begin{array}{l}\text { Local } \\
\text { farmers }\end{array}$ \\
\hline $\begin{array}{l}\text { Oven/Baking } \\
\text { tin }\end{array}$ & Cooking & Jua kali & $\begin{array}{l}\text { small- } \\
\text { large/200g- } \\
2 \mathrm{~kg}\end{array}$ & Jua kali & $\begin{array}{l}8000- \\
30000 / 70- \\
350\end{array}$ & $8 / 1000$ & Locals \\
\hline Improved Jiko & Cooking & Jua kali & $9 \_22$ & Jua kali & $180-3500$ & 600 & Locals \\
\hline $\begin{array}{l}\text { Oven/ } \\
\text { Improved Jiko }\end{array}$ & Cooking & Jua kali & $\begin{array}{l}2 \mathrm{ft}-4 \mathrm{ft} / 8 "- \\
22 "\end{array}$ & Jua kali & $\begin{array}{l}6000- \\
48000 / 120- \\
3000\end{array}$ & $40 / 2500$ & Locals \\
\hline $\begin{array}{l}\text { Oven/improved } \\
\text { Jiko }\end{array}$ & Cooking & Jua kali & $\begin{array}{l}\text { smal-large/9- } \\
24\end{array}$ & Jua kali & $8000-28000$ & $23 / 100$ & Locals \\
\hline Oven & Cooking & Jua kali & $2.5 \mathrm{ft}-5 \mathrm{ft}$ & Jua kali & $\begin{array}{l}12000- \\
45000\end{array}$ & 15 & Locals \\
\hline
\end{tabular}

\section{Supermarkets}

In supermarkets the technologies that were available included sorting, cooking and storage all these were sold to the locals. Technologies included the modern cookers made by several companies with sizes ranging from $50 * 60$ to $56 * 60$ for cookers and $10 \mathrm{~L}$ to 25L microwaves and sold between KES 23995/- to 75995/- for cookers and KES5000/- to 15000/- for microwaves . For storage technologies fridges were available in different sizes ranging from 183L-535L costing between KES30995-85995 all the these information is captured in the Table1.8 below. Prices in supermarkets were however higher than in Jua Kali. 
Table1.8 Case summaries for Post-harvest technologies in Supermarkets

\begin{tabular}{|c|c|c|c|c|c|c|c|}
\hline tem & $\begin{array}{l}\text { use of } \\
\text { technology }\end{array}$ & model/brand & $\begin{array}{l}\text { available } \\
\text { size }\end{array}$ & supplier & price & $\begin{array}{l}\text { quantities } \\
\text { sold P.A }\end{array}$ & $\begin{array}{l}\text { Customers } \\
\text { buying }\end{array}$ \\
\hline Sieve & Sorting & plastic & $\begin{array}{l}\text { small- } \\
\text { Large }\end{array}$ & Kenpoly & $10-500$ & 2000 & Locals \\
\hline Sieve & Sorting & plastic/Metal & 8-18321 & Minimax & $15-75$ & 18000 & Locals \\
\hline Sieve & Sorting & Kenpoly & $1-7$ & Kenpoly & $12 \_60$ & 1000 & Locals \\
\hline Cookers & Cooking & Armco & $\begin{array}{l}50 * 60- \\
56 * 60\end{array}$ & Armco & $\begin{array}{l}23995- \\
75995\end{array}$ & 500 & Locals \\
\hline Fridges & Storage & Samsung & $\begin{array}{l}183 \mathrm{~L}- \\
535 \mathrm{~L}\end{array}$ & Samsutech & $\begin{array}{l}30995- \\
85995\end{array}$ & 500 & Locals \\
\hline Microwave & Cooking & Rn551 & $10 \mathrm{~L}-25 \mathrm{~L}$ & Ramtons & $\begin{array}{l}5000- \\
15000\end{array}$ & 100 & Locals \\
\hline
\end{tabular}

\section{Farmer's knowledge on the post-harvest harvest technologies}

We tried to find out if farmers were aware of the existence of the technology and the response was a strong yes ( 1 indicated a yes) from all those interviewed that farmers were aware, further tried to find out the ability of farmers to use the post-harvest technologies from the Table below we can see that most farmers knew how to use the technologies well, all the machines from the various technologies were effective and sellers knew well how to use the machines it was rated on a scale of 1 to 5 and most showed a rate of 4 and 5 giving an average of more than 4 this was analyzed at 95\% confidence interval as shown in Table 1.9 below.

Table 1.9: Farmers Knowledge on the existence of the Technologies

\begin{tabular}{|l|l|l|l|l|}
\hline & Minimum & Maximum & Mean & Std. Deviation \\
\hline $\begin{array}{l}\text { Awareness of the existence of the } \\
\text { technology }\end{array}$ & 1 & 1 & 1.00 & .000 \\
\hline $\begin{array}{l}\text { Framers Knowledge on how to use the } \\
\text { technology }\end{array}$ & 2 & 5 & 4.33 & .816 \\
\hline Effectiveness of the technology & 3 & 5 & 4.69 & .592 \\
\hline $\begin{array}{l}\text { Ability of sellers to use the } \\
\text { technology }\end{array}$ & 3 & 5 & 4.77 & .497 \\
\hline Valid N (listwise) & & & & \\
\hline & & & & \\
\hline
\end{tabular}

\section{Reliability Statistics}

From the Table below (1.10) the Cronbach's alpha value is 0.181 which indicates a fairly high level of internal consistency for our scale with this sample.

Table 1.10 :Reliability Statistics

\begin{tabular}{|l|l|}
\hline Cronbach's Alpha & $\mathrm{N}$ of Items \\
\hline .181 & 11 \\
\hline
\end{tabular}

\section{CONCLUSION}

It was noted that most post-harvest technologies were not utilized by farmers therefore there is need for the relevant authorities to do awareness on available methods of post-harvest handling and agro processing of food and feed. At the point of sale too it was noted that those who were in such businesses would also be educated on the existence of other post-harvest technologies so that when farmers visit them then they could educate them. Most of the cheap technologies were locally made in the jua kali as compared to supermarkets which were more expensive. There is need for the jua kali artisans to be trained on how to modernize so as to be able to sell some of their products to the supermarkets and for them to be able to commercialize the production of the postharvest technologies. There is a need for an exhibition with the stakeholders to create awareness on all post-harvest technologies available in the market place.

\section{REFERENCES}

[1] FAO (2015). The state of food and agriculture http://www.fao.org/publications/sofa/

[2] FAO, (2015). Undernourishment in 2010 by region (millions). Viewed $5^{\text {th }}$ September 2015, http://www.fao.org/hunger/hunger_graphics/en/

[3] GoK, (2013). National Climate Change Action Plan 2013- 2017. Nairobi: Government Printers.

[4] Hodges, R.J; Buzby, JC; and Bennet, B. (2011). Postharvest losses and waste in developed and less developed countries: opportunities to improve resource use. Journal of Agricultural Science 149: 37 - 45.

[5] IFPRI (2015). Feeding the World: Sustainable Agriculture Innovation in the $21^{\text {st }}$ Century. RIO +20 . 
[6] Nyambo B.T (2013). Post-harvest maize and sorghum grain losses in traditional and improved stores in South Nyanza District, Kenya: International Journal of Pest Management 39: 181 - 187

[7] Suvedi, M. \& Kaplowitz, M. (2016). What Every Extension Worker Should Know-Core Competence Handbook. Michigan State University. Michigan, USA.

[8] Tabachnick, B. G., \& Fidell, L. S. (2007). Using multivariate statistics (5th ed.). Allyn \& Bacon/Pearson Education.

\section{AUTHORS}

First Author - Ouma, R.O, Masters, Rongo University, robouma@yahoo.com

Second Author - Mugalavai, V.K, PhD, University of Eldoret, violet.mugalavai@gmail.com

Third Author - Onkware, A. O PhD, Rongo University, aonkware@yahoo.com 